\title{
The Hindrances to Obtaining Protected Geographical Indications for Products in Mexico. Case Study of Dairy Farming in the Cienega de Chapala, Michoacan
}

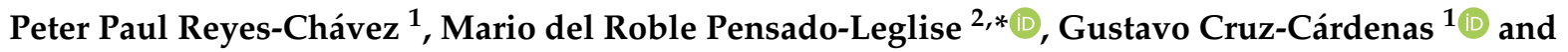 \\ Rebeca Flores-Magallón ${ }^{1}$ \\ 1 Instituto Politécnico Nacional, CIIDIR-Unidad Michoacan, COFAA, Jiquilpan 59510, Mexico; \\ preyesc1700@ipn.mx (P.P.R.-C.); guscruz@ipn.mx (G.C.-C.); refloresma@ipn.mx (R.F.-M.) \\ 2 Instituto Politécnico Nacional, CIIEMAD, Proy SIP20201099, Ciudad de México 07340, Mexico \\ * Correspondence: mpensado@ipn.mx
}

check for

updates

Citation: Reyes-Chávez, P.P.;

Pensado-Leglise, M.d.R.;

Cruz-Cárdenas, G.; Flores-Magallón,

R. The Hindrances to Obtaining

Protected Geographical Indications for Products in Mexico. Case Study of

Dairy Farming in the Cienega de

Chapala, Michoacan. Sustainability

2021, 13, 6701. https://doi.org/

$10.3390 /$ su13126701

Academic Editors: Giovanni Belletti,

Filippo Arfini, Andrea Marescotti,

François Casabianca,

Emilie Vandecandelaere and

Junko Kimura

Received: 18 March 2021

Accepted: 8 June 2021

Published: 12 June 2021

Publisher's Note: MDPI stays neutral with regard to jurisdictional claims in published maps and institutional affiliations.

Copyright: (c) 2021 by the authors. Licensee MDPI, Basel, Switzerland. This article is an open access article distributed under the terms and conditions of the Creative Commons Attribution (CC BY) license (https:// creativecommons.org/licenses/by/ $4.0 /)$.

\begin{abstract}
The aim of this article is to analyze why there are hindrances to the development of PGI products in Mexico, based on the case study of dairy farming in the Cienega de Chapala, Michoacan. Currently, local dairy production satisfies the demand of a parastatal company, marginally supplies the local consumption of fresh milk and is the supplier of the input for the production of a typical low-value ranchero cheese with local demand. In addition, there was a negative impact of NAFTA on local products, and it persists with the recent USMCA. However, with further development of collective action of local dairy farmers, it is possible to promote PGIs for the regional market by taking advantage of the opportunity offered by the new labeling policy of the current federal government. The methodology is a combination of qualitative and quantitative; 68 interviews were conducted with dairy farmers in the study area, and MFA and ATLAS.ti software were used. The results highlight that socio-environmental problems and market failures are related to the obstacles such as the lack of collective action of dairy farmers and the absence of a local governance system that regulates the market and promotes quality, food safety and sustainable practices in the territory.
\end{abstract}

Keywords: protected geographical indication; dairy farming; ranchero cheese; local governance; market and institutional failures; environmental degradation; Cienega de Chapala

\section{Introduction}

Recent analyses of the aftermath of the COVID-19 pandemic [1] suggest raising the need for adjustments to make food production and consumption sustainable and to encourage reflection on how a PGI good should be linked to a sustainable type of rural territorial development [2]. In the case of Mexico, the official quality distinction of territorial products has been scarce, as so far only eighteen goods with protected designation of origin (PDO) have been legally recognized, and some of them were so because they were the demands of big business consortiums or of bureaucratic actions that are later exploited by industrial interests for export purposes [3] rather than true recognition of territorial cultural identities and organized peasants. This is surprising because there are many territorial products with quality distinction, history and social prestige. Today, in Mexico, there are obstacles to the development of PDO and PGI goods that hinder the possibility of sustainable territorial development, prevent the consolidation of well-organized local food systems and contribute to the degradation of the environment, putting the conservation of the landscape heritage at risk. However, it is unclear why producers are not organized or not interested in having their products considered as specialty goods. The aim of this paper is to answer the question of why there are hindrances to the development of PGI products in Mexico, based on the case study of dairy farming in the Cienega de Chapala, Michoacan.

In the current post-Fordist era, the expansion of an increasingly heterogeneous social consumption of food has made possible the flexibility of production and the segmentation 
of markets, leading to an accelerated differentiation of goods and versatility of food qualities. The generalization of cultural counter-trends to globalization opened the possibility of revaluing and generating new niches for traditional local products in the global market. This happened through the creation, production and revaluation of specialty goods of a differentiated nature and that have different degrees of quality according to the social income stratum corresponding to each niche or market segment [4].

Quality, then, is valued and socially agreed upon [5] according to the specific specialty good and its niche of differentiated consumption [6], regardless of its nature or provenance; whether it is an item from alternative food networks [7,8]; its proximity status [9]; its short food chain status [10]; its fair trade status [11]; its organic, urban agriculture or agroecological status [12]; or whether it is a PDO or a PGI [13], independent to be considered as a public good or a club good [14] or how some call it, a toll good [15]. In all cases, the set of attributes that define the quality of a good generate intrinsic motives [16] and extrinsic motives to the type of consumer that explain their desire to consume it [17]. These are linked to different classes of elements of the physical, biochemical, organoleptic order; of the sensory, emotional and cognitive framework of its typicity; of the reputation of the producer; of distinctive social knowledge or historical place of origin; of appreciation of the social conception; or of a cultural, practical or convenience identity for the specific purposes of its hedonic consumption [18]. The signs of the quality of a good and the social convention [19] are the tools with which society identifies it, legitimizes it and values it as a specialty good.

In the case of cheeses as PDO and PGI goods, the typicity of the good [20] is a complex manifestation of the interaction of natural, environmental, technical, historical, social, economic, relational and institutional cultural forms associated with a territorial social identity and its connection to a process of patrimonialization of a landscape that offers a cognitive and tacit framework to PDO and PGI goods [21]. Therefore, the classification of PDO and PGI goods, based on their typicity, requires an intricate adoption of a code of practice that includes the incorporation of landscape heritage into the nature of these assets [22].

However, there are endogenous and exogenous threats and pressures on the development of PDO and PGI goods. For example, it is not only the problem that there are global companies that want to be the exclusive profit makers of PDO and PGI products [23], because there are also free riders who seek rewards for counterfeiting these products. Such circumstances involve the need for a collective action and the mobilization of resources of the small producers to create an effective marketing strategy based on their common code of practice established within their geographic boundaries [24,25]. In addition, they require effective institutional legal protection from the state to successfully develop PDO and PGI goods. This process of collective action must include strengthening producers' relationships with other social actors of the territory to develop a landscape patrimonialization of goods throughout the territory [26] that strengthens the residents' social identity and leads to an "expanded" territorial strategy that includes the construction of a basket of rural goods developed in that territory [27]. In this way, this contributes to creating a territorial incentive structure that discourages free riders because it makes it possible to offer a variety of collateral activities with jobs and better incomes, which improve the chances of boosting PGIs.

A more recent challenge for PDO and PGI food goods is the current COVID-19 pandemic and its relationship with the process of climate change. Human mortality in December 2020 reached 1.7 million deaths, which will further impact the decision of global society to change its pattern of food consumption towards a healthier diet [28]. As we have seen, the social construction of PGIs has tended to be of a more polyvalent nature. Now, not only must a PGI fulfill the functions demanded by the consumer in its market niche, but it must also be associated with good environmental practices, be food-safe, be a nutritious food and contribute to sustainable territorial development. 
Therefore, analyzing the hindrances faced by the development of a cheese as a PGI product implies reviewing the evolution of its history linked to a territory; observing the opportunity offered by the current advantages and disadvantages of its possible development; and weighing the strengths and weaknesses of the main social actor involved, its actor profile, the importance of its local origin, its economic and environmental problems and the adoption of its productive strategy. For this reason, these topics are addressed in this study.

\section{Case Study Presentation}

The cow's milk market in Mexico is characterized by a deficit, is a big importer of skim milk powder and has an oligopolistic structure, with only two large companies dominating about $70 \%$ of the domestic market [29]. These conditions hinder the growth of regional dairy markets and in particular the development of PGI goods.

Dairy farming of the Cienega de Chapala, Michoacan, is a product of a landscape heritage in which the natural characteristics of a territory converge with one of the largest lakes in Mexico, with a continuous hydrodynamic system [30] that allowed the configuration of an extraordinary space of geoforms, soils and biota, as well as the historical, social, and cultural characteristics of the process of space anthropization [31] that has been the product of a continuous succession of human communities that have formed a diverse, unequal and complex regional society, with a vast cultural richness and closely linked to the history of the country. Here, the space formed by four municipalities (Marcos Castellanos, Sahuayo, Jiquilpan and Venustiano Carranza) that occupy part of the mainland and part of the dried-up area the Cienega of Lake Chapala, located in the state of Michoacan, is called the "territory of Cienega de Chapala".

After the Spanish conquest, transhumance cattle raising was used to take over the space and was, in practice, nomadic ranching, which provided food for the colonization process of New Spain, the development of new cities and support for mining activity [32]. In its historical evolution, the nomadic cattle trade served to transport crafts and trade livestock by-products such as leather, skins and cheeses. When nomadism was no longer useful, a broad food trade network was generated in which the ranchers [33] of the Cienega de Chapala, an agricultural region of excellence, played a role that was complementary and subordinate to the dynamics of the haciendas [34] from the center-west of the country, providing grains, fresh vegetables, fruits, beef, milk, cream, butter and cheese. At present, the predominant agricultural activity here is dairy farming, which is oriented towards the sale of fresh milk to the parastatal company Liconsa, the marginal sale of fresh milk directly to the public and the sale of milk to cheese companies either directly or through collectors for the production of a traditional fresh cheese, which is the favorite in the popular taste of the regional short circuit.

In the Lake Chapala basin, dairy farming is distinguished by the production of two types of cheese. The first of these is Cotija cheese from the Sierra Jal-Mich, which is made with milk obtained only in the rainy season from cows fed on the natural grasslands of the Sierra. This cheese is traditional, and its typical flavor gives it a social reputation and better price, so knock-offs have been made by other manufacturers [35]. Given its typicity and quality, it has been recognized in international competition, and a collective trademark has been registered [36].

The second type is fresh ranchero cheese, which is made with fresh milk produced in the territory of the Cienega de Chapala, a focus of the present work. It is produced in small wheels $(1 / 2,1$ and $5 \mathrm{~kg})$ made from the milk of cows fed with alfalfa and induced and natural grasslands. It is made in industrial facilities or in artisanal family workshops in any of the four Michoacan municipalities mentioned that make up the territory of the Cienega de Chapala. The virtue of this cheese has its roots in the colonial era; as a fresh cheese, it can be consumed little by little in the home since it is protected from dust and insects when left in the open air, and as it ages, it can accompany different dishes of Mexican cuisine. This ranchero cheese became popular because it was easy to preserve on trips and was a 
favorite food (often combined with corn tortillas, beans and chili) of the "arrieros" who transported goods and of those who herded the cattle from the Cienega de Chapala to supply the mining centers and some cities of New Spain.

The rancheros that produced this cheese in the 20th century were dairy farmers, but their idiosyncrasy and desire to be independent producers have not favored the success of official programs to improve practices in dairy farming, as their marked individualism has prevailed [37]. In recent decades, productive heterogeneity among dairy farmers has increased. On the one hand, a minority of large dairy producers have adopted the technological innovation of the "Holstein model" [38], intensifying their activity, integrating their agricultural and livestock production and increasing their economies of scale and investment costs. In addition, the large producer became the owner or partner of the small and medium dairy and ranch cheese company. The growth of cheese companies required the collection of milk produced by small farmers or, since the North American Free Trade Agreement (NAFTA) [39], increased the use of imported skim milk powder (inexpensive and without tariffs), which they mixed with vegetable fats. This put heavy price competition on small, local dairy farmers in addition to producing imitation dairy products.

On the other hand, the majority of small, scattered dairy farmers try to keep reducing their operating costs as much as possible to sell their official milk quota to Liconsa and their surplus milk to collectors or to cheese companies. This implies that some dairy farmers use part of their surplus milk to make fresh cheese in their family workshops, but some do so with poor sanitary conditions. The largest sales of legitimate ranchero fresh cheese are made to the low- and medium-income population of the rural and peri-urban short food circuit near the Cienega de Chapala and the cities of the states of Jalisco, Colima and Michoacan, but the reputation of this cheese as a local product transcends borders because it is appreciated by migrants who return annually and take it to their communities in the United States. Today, the market is characterized by adulterated milk; imitations of cheeses; products with sanitary deficiencies; a lack of transparency and information about ingredients that can cause gastrointestinal diseases; and the consumption of an industrial imitation product with vegetable fat that contains few proteins and vitamins, excess fats and excess carbohydrates [40]. This situation has brought about the possibility that there is a single price both for authentic local milk and cheese and for products with sanitary deficiencies or dairy products of low nutritional quality [41].

In 2019, a research team worked on good hygiene practices in family cheese workshops conducted by Dr. R. Flores Magallón of CIIDIR, Michoacan, IPN, during the period from July to November 2019 in the territory of La Cienega (municipalities of Sahuayo, Jiquilpan, Venustiano Carranza and Marcos Castellanos); she participated and collaborated with dairy producers and members of local livestock associations concerned about the quality of their product. The microbiological quality of 200 fresh cheese samples ( 50 pieces per municipality) of $500 \mathrm{~g}$ each was assessed. The laboratory tests were based on sanitary standards, and the following results were obtained: In all cases, there were sanitary deficiencies in their production due to poor conditions of the workshop, equipment and clothing, which affect cheese making. The majority of the samples were contaminated, and the presence of microorganisms exceeding the allowed levels of E. coli, Salmonella sp., Listeria monocytogenes and Staphylococcus aureus stood out. Based on that work, it has now been proposed to establish, together with small dairy producers, a program of good practices of manual milking and hygienic manufacturing procedures that improve the microbiological quality of these foods.

The new federal government of President A.M. López Obrador has promoted a change in public policy for the dairy sector, but its signs are self-contradictory and are as follows:

(a) With the signing of the United States-Mexico-Canada Trade Agreement (USMCA) in early 2020, it is still advantageous to import skim milk powder [42], which combined with vegetable fats or starches leads to a greater yield of industrialized dairy product for the parastatal company Liconsa and for the imitation of cheeses made by local 
companies. This is detrimental to the production of quality milk and cheese from the Cienega de Chapala.

(b) In terms of regulations, in 2012, the Mexican official norm NOM-155 [43] was established, which defines the whole raw milk of animals as well as their variants, names and specifications. However, that same year, based on the CODEX Alimentarius 2006 [44], the Mexican official norm NOM-190 was also established; it defines mixtures of milk with vegetable fat [45], but in practice, it served to continue tolerating the use of the name "milk" for the imitation product. This made it easy for cheese companies to use these mixtures to also produce imitation cheese products, although in January 2019, the Mexican official norm NOM-223 confirmed that cheese could only be made with $100 \%$ animal milk [46].

(c) Liconsa, with the implementation of the modification to the Mexican official norm NOM-051 [47], which defines practices for food labeling, declared that it had modified its industrial formulation and decreased the content of vegetable fats, but had not eliminated them, and will continue to use mixtures of imported skim milk powder and vegetable fat to maintain production volume and low prices for its milk formula called "Leche" Liconsa.

(d) In 2019, the parastatal company Liconsa raised the official price of fresh milk that it collects directly from dairy farmers by an average of $30 \%$ (with respect to the current average price of 2018), without considering the sanitary quality. For this reason, dairy farmers have been favored, but this has not prevented some of them from continuing their bad environmental and safety practices in cheese production [48].

(e) The change in government policy against obesity and overweight led to the aforementioned modification of the Mexican official norm NOM-051, which sets food labeling standards and forces manufacturers and sellers to indicate the real content of products and add warnings about excess sugars, carbohydrates and calories. On 1 July 2020, the Quality Infrastructure Law was published [49], which requires compliance with official product norms.

These changes in regulations allowed the Federal Attorney for Consumer Protection (Procuraduria Federal de Proteccion al Consumidor) of Mexico, in October 2020, for the first time in its history, to prohibit large companies from using the name "milk" or "cheese" for imitation dairy products or products that do not comply with the indications prescribed for their content. This new public policy offers the expectation that food will stop being adulterated and local products will stop being imitated, giving hope for the development of PGI goods. However, without collective action, it will be difficult for the new rules to be used and to last over time.

\section{Materials and Methods}

The study area is northwest of the state of Michoacan, located in central-western Mexico at an average altitude of 1524 AMSL. Its climate is semi-warm temperate and subhumid, with an average annual temperature of $19.7^{\circ} \mathrm{C}$ and an average annual rainfall of $853 \mathrm{~mm}$ (Figure 1) The predominant vegetation is still unaltered subtropical scrub in the upper parts of the oak forest, and the main land use is agricultural. This is closely linked to the relief of the region and the type of soil, and the slopes of mountains and valleys are the areas most commonly used for livestock. Four milk-producing municipalities were selected from this area: Jiquilpan, Marcos Castellanos, Sahuayo and Venustiano Carranza. Regarding the land set aside for livestock use, it is mainly used for cattle, and although there are cattle for meat production, dairy cattle are the main economic asset. 


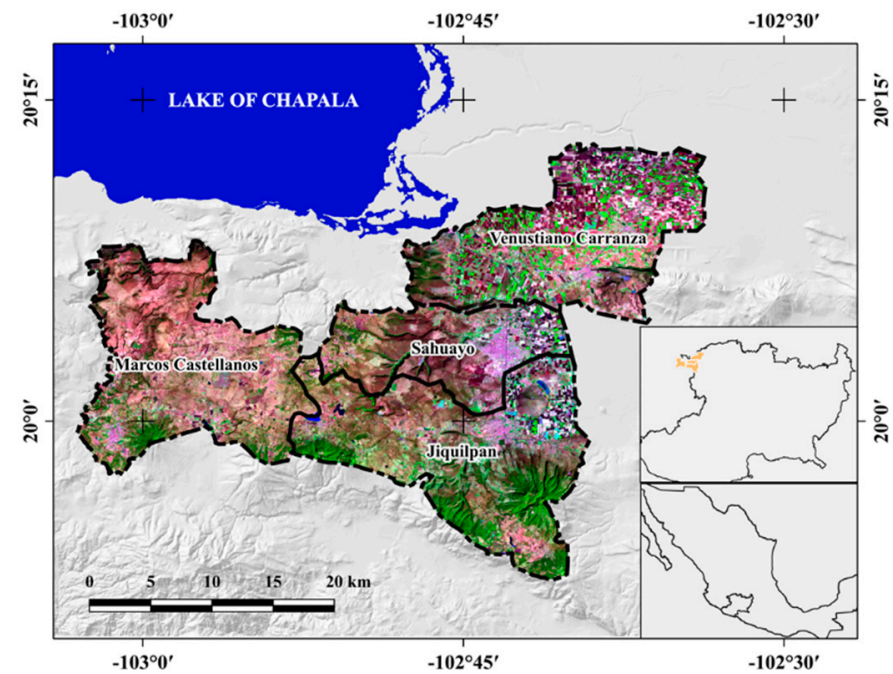

Figure 1. Geographical location of the study area.

In the last 13 years, within this territory, only in Venustiano Carranza and Sahuayo has there been a dynamic of relevant economic growth, although Marcos Castellanos has more than half of the production value of this territory since most of the induced grasslands of the territory are found there (Table 1).

Table 1. Dairy cattle in the Cienega de Chapala, Michoacan, in 2006 and 2019.

\begin{tabular}{ccccccc}
\hline Variables & \multicolumn{3}{c}{ Volume } & \multicolumn{3}{c}{ Values in 2019 Fixed Prices } \\
\hline Years & 2006 & 2019 & AAGR & 2006 & 2019 & AAGR \\
\hline Jiquilpan & 6827.5 & 7235.7 & 0.4 & $41,868.5$ & $47,466.0$ & 1.0 \\
\hline Marcos Castellanos & $34,896.2$ & $38,179.2$ & 0.7 & $212,793.1$ & $266,722.7$ & 1.8 \\
\hline Sahuayo & 7586.1 & $13,745.9$ & 4.7 & $46,116.7$ & 9622.0 & 5.8 \\
\hline Venustiano Carranza & 7965.4 & $13,498.4$ & 4. & $48,963.8$ & $102,619.4$ & 5.9 \\
\hline $\begin{array}{c}\text { Territory: Sum of } 4 \\
\text { municipalities }\end{array}$ & $57,275.3$ & $72,659.2$ & 1.8 & $349,742.0$ & $513,029.1$ & 3.0
\end{tabular}

Volume: thousands of liters of milk; Value: thousands of pesos; AAGR: average annual growth rate; Source: by authors based on: http:/ /infosiap.siap.gob.mx (accessed on 11 December 2020).

According to the objective of the work, the methodology is aimed at explaining the reason for the existence and nature of the material and relational obstacles that farmers face and that make it difficult for them to generate the development of queso ranchero fresco as a PGI good.

To this end, a total of 1061 farmers registered in local livestock associations were considered, located in the four municipalities that make up the territory, and observing that their economic dynamism is heterogeneous, a stratified random sampling design was employed, which resulted in a total of 68 farmers (Table 2).

Table 2. Livestock farmers registered and statistical sample by municipality.

\begin{tabular}{cccc}
\hline Municipality & Livestock Farmers & Percentages & Respondents \\
\hline Marcos Castellanos & 450 & 42.1 & 28 \\
\hline Jiquilpan & 120 & 11.3 & 8 \\
\hline Sahuayo & 241 & 22.7 & 16 \\
\hline Venustiano Carranza & 250 & 23.5 & 16 \\
\hline Total & 1061 & 100 & 68 \\
\hline
\end{tabular}


The selection of the sample was made based on the following equation:

$$
n=\frac{N * Z_{\alpha}^{2} * p * q}{d^{2} *(N-1)+Z_{\alpha}^{2} * p * q}
$$

where $N=$ total population, $Z \alpha=1.96, p=$ expected proportion $(0.05), q=1-\mathrm{p}(0.05)$, $d=$ precision $(5 \%)$, and $n=$ samples.

This paper proposes, five indispensable factors for livestock activity in north-western Michoacan, which are as follows: (1) profile, for which we considered the main characteristics of dairy farmers and the type of livestock management; (2) permanence, for which we analyzed whether being born or living in the territory was culturally relevant in the type of dairy farming practiced; (3) economy, for which we observed the economics of the different types of production systems and their relationship with the milk market; (4) environmental, for which the perception of the farmer of the local environmental status was considered; and (5) livestock strategies, for which the actions and strategies of the farmers were reviewed.

Based on this information, two types of analyses were performed. The first was based on quantifying the statistical frequencies of the responses of each variable (quantitative and/or qualitative), and multiple factor analysis (MFA) was applied to the management of both quantitative and qualitative variables. Several dimensions were generated to give certainty, the dimensions with the highest percentage of variance representation and which are part of the set of those necessary to achieve a cumulative variance greater than $60 \%$ were selected [50,51]. For visualization, graphs generated by the comparison between categories contained in two dimensions were obtained. Correlations were determined by their position in the plane as stated by the MFA [52]. To develop the MFA, the R software was used. In the second analysis, based on the $28 \mathrm{~h}$ of interview recordings, the heuristic method of qualitative research was used with ATLAS.ti 7.0 software. For the selection of the farmers to interview, stratified random sampling was applied, from which 68 interviews were obtained with registered dairy farmers from the four municipalities of the study. Then, their responses were coded, and the types of relationships found in dairy farming were analyzed.

To do this, a procedure is followed to identify relevant themes and ideas in the interviews, which are then used to define keywords as codes, which are often repeated throughout the various interviews; finally, a map or outline is obtained with the relevance of each code. This map makes it possible to visualize and describe the phenomenological situation from the researcher's analysis based on the results obtained from the field research [53]. The application involves a contrast of subcategories or first categories, properties and hypotheses that emerge throughout a study in successive frameworks or contexts. This procedure is developed in four stages: (1) understanding the data, (2) definition and integration of each category, (3) delimiting the subject and object of study and (4) explanation of the phenomenon found and studied [54].

\section{Results}

\subsection{Results of the Relationships between Categories by MFA}

The MFA highlighted the main factors driving farmers' variability. A balance between the influence of the different groups in the analysis was obtained by weighting the various data tables. There were 19 variables used for the model exercise (see Table 3). 
Table 3. Variables used for the model.

\begin{tabular}{|c|c|c|}
\hline No. and Type of Variable & Factor & Subject \\
\hline \multicolumn{3}{|l|}{ Quantitative } \\
\hline 1 & Profile & Age \\
\hline 2 & Profile & Schooling \\
\hline \multicolumn{3}{|l|}{ Qualitative } \\
\hline 3 & Profile & Cattle breed \\
\hline 4 & Permanence & Years of breeder \\
\hline 5 & Permanence & Continuity of the family \\
\hline 6 & Permanence & $\begin{array}{c}\text { Possible permeance or withdrawal } \\
\text { of livestock }\end{array}$ \\
\hline 7 & Permanence & $\begin{array}{c}\text { Secondary activities compatible } \\
\text { with livestock }\end{array}$ \\
\hline 8 & Economic & $\begin{array}{l}\text { Income from livestock is sufficient } \\
\text { for the family }\end{array}$ \\
\hline 9 & Economic & $\begin{array}{l}\text { How can you obtain greater } \\
\text { monetary gain with livestock }\end{array}$ \\
\hline 10 & Economic & $\begin{array}{l}\text { There is government aid to } \\
\text { livestock }\end{array}$ \\
\hline 11 & Economic & $\begin{array}{l}\text { The import of powdered milk as a } \\
\text { substitute for fresh milk }\end{array}$ \\
\hline 12 & Environmental & Fertility of livestock soils \\
\hline 13 & Environmental & Agriculture for livestock \\
\hline 14 & Environmental & $\begin{array}{l}\text { The sum of agriculture and } \\
\text { livestock in the environment }\end{array}$ \\
\hline 15 & Environmental & $\begin{array}{l}\text { Impact on the environment, how to } \\
\text { minimize it }\end{array}$ \\
\hline 16 & Livestock Strategy & Subsistence in the dry season \\
\hline 17 & Livestock Strategy & Density on land \\
\hline 18 & Livestock Strategy & $\begin{array}{c}\text { Management on land and its } \\
\text { techniques }\end{array}$ \\
\hline 19 & Livestock Strategy & Modernization of livestock \\
\hline
\end{tabular}

In this way, it was possible to observe relationships between the different groups. In addition, the degree of similarity between the observed individuals was determined [55]. Subsequently, a map of the partial axes was made that allowed us to see how the factors generated by the separate analyses are related (Figure 2). In MFA, 59 dimensions were generated, 8 of which represented $60 \%$ of the variance contribution (Annex); positively correlated variables were grouped together or were near each other, while negatively correlated variables were placed in opposite quadrants. The results shown below are the interpretations of dimensions one and two, which explain only $20.7 \%$ of the accumulated variance. The low percentage is mainly due to the fact that the cumulative variance is distributed in a greater number of dimensions. However, as in principal component analysis, the first dimensions are the most representative. 


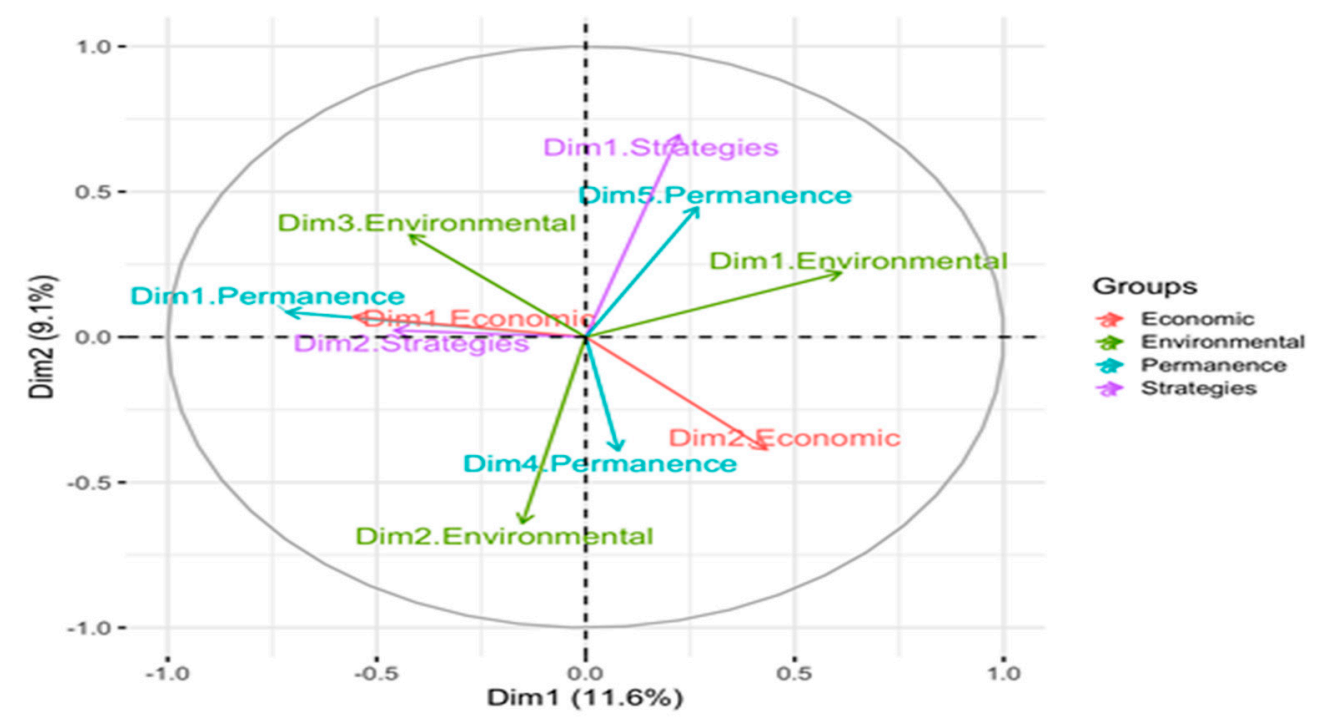

Figure 2. Graph of the relationship of the categories with dimensions 1 and 2.

Despite the low explanatory power of the model, some partial correlations remain that can be considered in the analysis of dairy farming. These are as follows: (1) The results show a correlation of factors located in the same quadrant and dimensions close to each other, which are related to livestock, economic and environmental strategies. (2) It can be inferred that the profile of the dairy farmer is not a relevant factor and that such profile characteristics are independent of the economic, environmental and livestock strategy issues. (3) A primarily negative relationship is observed between the permanence factor and the other categories That is, the greater the severity of the economic and environmental issues is, the less permanent dairy farming is. (4) The positive correlation between the environmental, economic and livestock strategy categories is widely related. For example, when there is environmental damage, the erosion of pastures or overgrazing affects the profitability of the farmer; this implies adopting a livestock strategy of improving the forage production or complementarity with the purchase of alfalfa in the local market. (5) The over-heads of cattle per hectare is the main cause of the impact on the environment and on the economic health of livestock farmers. This may also help to explain the social heterogeneity among dairy farmers, their differences in interests and their avoidance of the adoption of a common livestock strategy.

\subsection{Results of the ATLAS.ti Analysis}

Based on the interviews, a grouping of the most frequent word categories was carried out, and an inductive coding was obtained that defined the supercodes of ATLAS.ti (the representative words are indicated along with how many times they were repeated on average for each interview) as seen in Table 4.

According to the coding generated by the ATLAS.ti analysis, there are nine supercodes that group the others (Table 3). Two markets stand out, the first being the main market that revolves around the production of fresh milk with a parastatal company and a local cheese-making activity as demanders. The second is the secondary market related to the cheese production system, which is divided in two, into the sale of industrialized cheese (fresh or imitation "Cotija"), which is associated with large dairy producers, and the sale of fresh ranchero cheese linked to the family workshops of small dairy farmers. The graphical representation of the relationships of the supercodes generated by ATLAS.ti can be seen in Figure 3. 
Table 4. Result of the inductive coding. Supercodes in the ATLAS.ti software exercise with the number of times indicated in the interviews (right side).

\begin{tabular}{ccc}
\hline Cheese Production Systems 38.1 & Integrated Farmers 39.1 & Collectors 13.6 \\
\hline Milk purchase b16.8 & Sowing, corn 11.3 & Roads, gaps, highways 3.3 \\
\hline Cheese 13 & Land, rain, fertilizers 9 & Dairy industries 9 \\
\hline Milk quality 5 & Safe of milk 5.3 & Milk payment, 1.3 \\
\hline Milk collection 3.3 & Stubble, silo 3.6 & \\
\hline Milk producers 65.5 & Grazing 9.8 & Liconsa 41.5 \\
\hline Cattle breed 7.83 & Forage producer 44.6 & Milk purchase 10.5 \\
\hline Water, livestock consumption 8.83 & Fater, irrigation, rainfed land 6.6 & High quality 7.3 \\
\hline Forage, pasture 16.5 & Fertilizer 10 & Supports, subsidies 7.5 \\
\hline Government support 6.5 & Lands, parcels 12.6 & Best price 16.1 \\
\hline Equipment 6.1 & Alfalfa, sorghum, corn 10.1 & \\
\hline Milk price 19.6 & Milk Powder Trade 41 & Local sale of fresh milk 6.3 \\
\hline Confectionary companies 3.8 & Fresh milk substitute 9.3 & Consumption at home 2 \\
\hline Milk purchase 2.1 & Low product quality 17.3 & Community buyout 2.1 \\
\hline Cajeta, eggnog, sweets 1.6 & Unfair competition 14.3 & Quality 2.1 \\
\hline
\end{tabular}

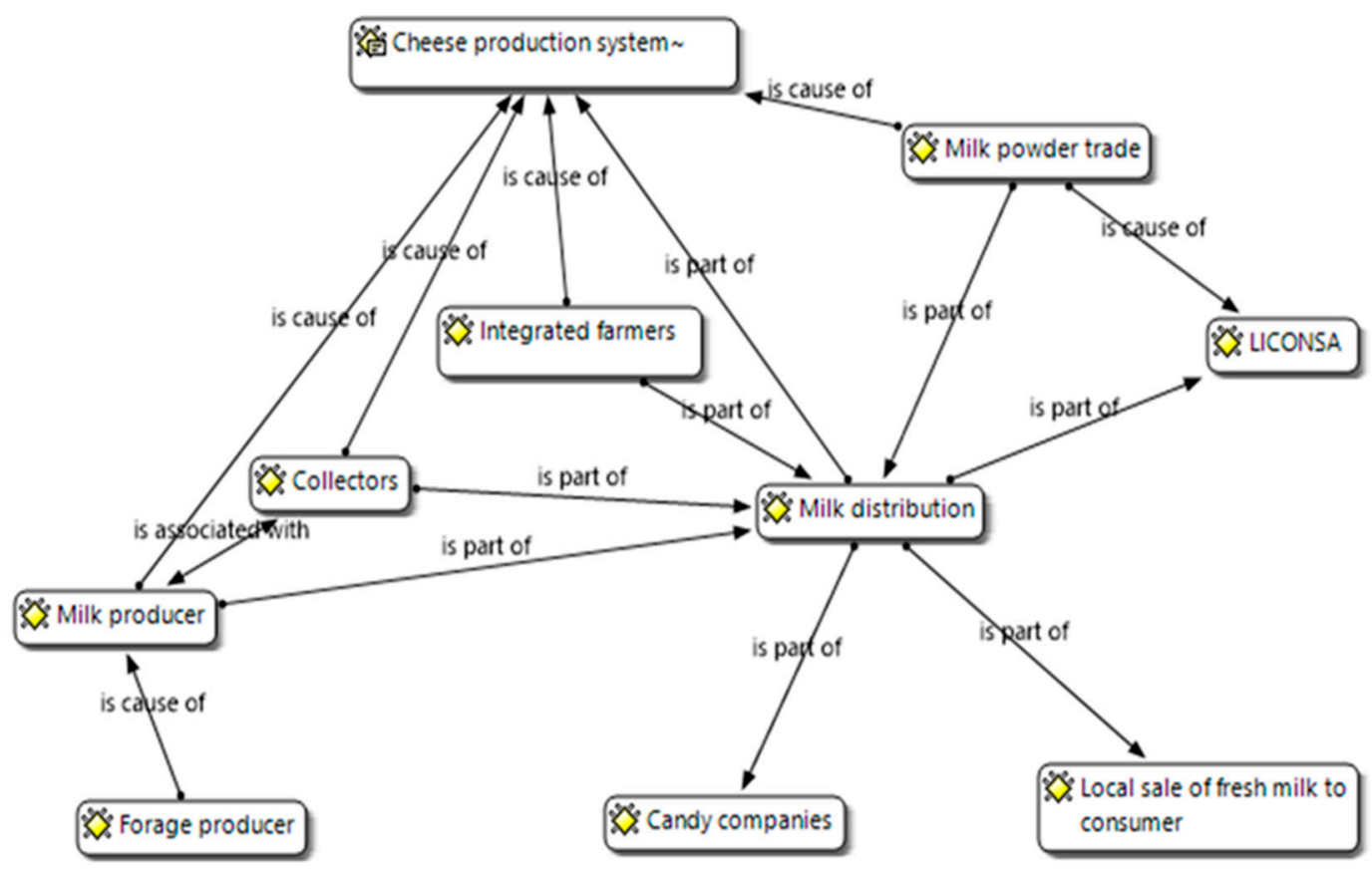

Figure 3. System of relationships of milk and cheese production in the Cienega de Chapala. Prepared by the authors in ATLAS.ti software.

In summary of the main problems arising from the analysis carried out, the following issues can be identified:list

(a) Types of dairy farmers

All dairy farmers can sell their volume quota to Liconsa and their surplus milk to the collectors or cheese companies, or they can eventually use it to make their own cheese. However, they have a low level of collective action, which limits their capacity for negotiation and favorable resource mobilization (Figure 4). 


\begin{tabular}{|c|c|c|c|}
\hline $\begin{array}{l}\text { Scenario } \\
\text { Constraints }\end{array}$ & Social actors & $\begin{array}{l}\text { Collective } \\
\text { Action }\end{array}$ & $\begin{array}{l}\text { Cheese-making } \\
\text { activities }\end{array}$ \\
\hline
\end{tabular}

Hyndraces for Development of PGI's cheese in case study

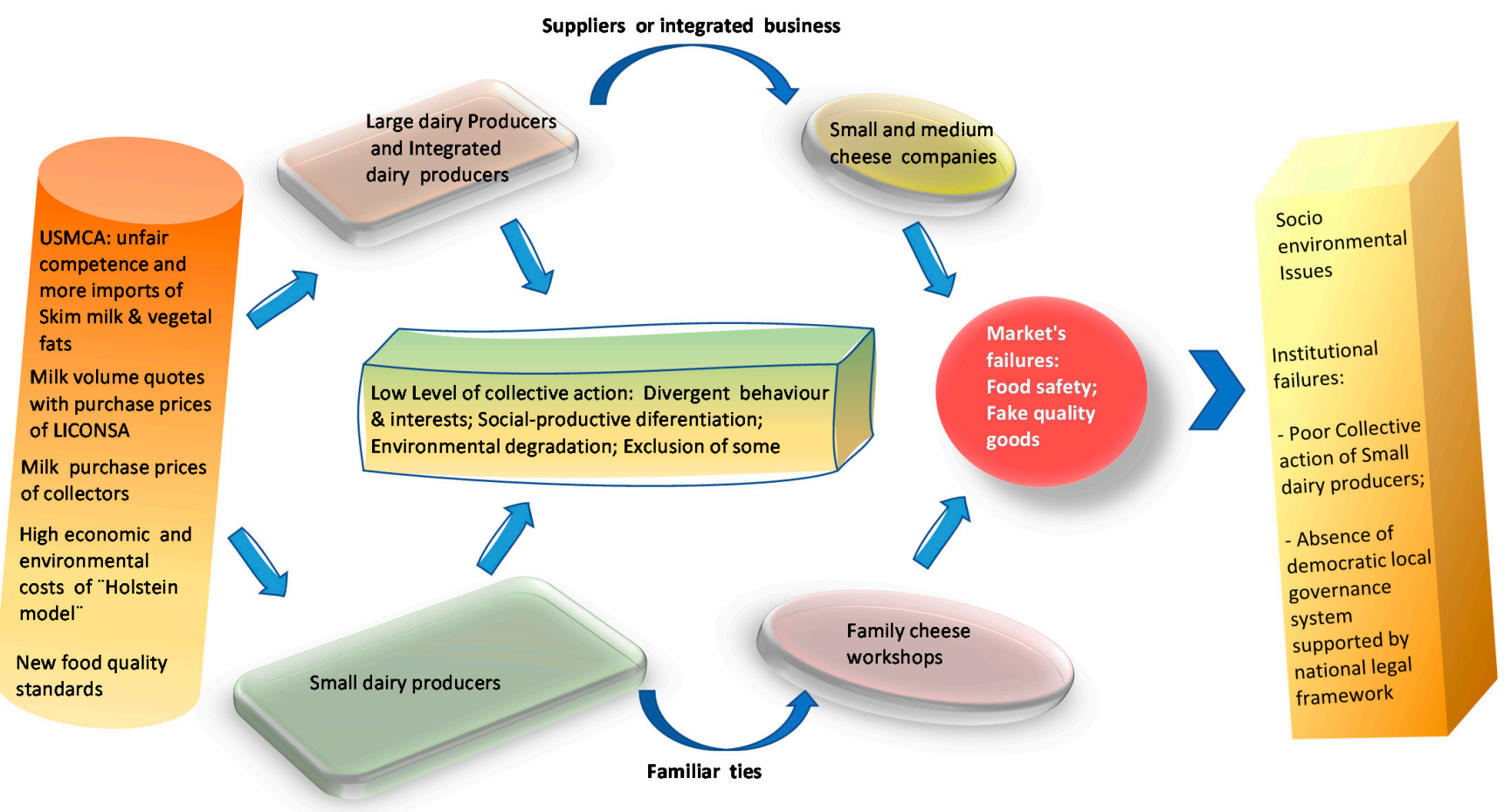

Historical evolution of "Ranchera" social identity and landscape heritage of he Cienega de Chapala, Michoacan

Figure 4. Framework of the relationship between collective action and the hindrances to PGI cheese development in the case study. Source: by authors.

In the case of large dairy producers, the advantage of their integration allows them to have their own cheese companies, further increasing the overall economic profitability of their activity [56]. Integrated livestock farmers are particularly well positioned, producing what the animals consume and sometimes supplementing it with seasonally purchased forage. Thus, they also manage the field, either cultivating alfalfa or forage or managing induced or natural grasslands with grass rotation.

In the case of small producers, family workshops to produce local cheeses provide them with the possibility of marginally improving their income because, in conditions of extreme savings, a family microenterprise generates profitability. The family workshop depends on having enough members of their family to produce artisanal cheese, but these dairy farmers are generally not interested in scaling up to industrial or commercial scale to become cheese entrepreneurs or in being part of a social enterprise. Their integration in the local cheese production circuit in a marginal way allows them to be suppliers of fresh milk, which takes up most of their time and generates satisfaction by preserving their rancher identity.

(b) Environmental conditions for dairy farming

Environmental degradation affects the livestock soil and fodder quality, which limits the dairy farmers' production, thus raising their costs by necessitating the purchase of additional fodder for feeding their dairy cattle; in the medium term, this leads to a problem of economic profitability. In the end, the farmers are faced with one of two options: either 
they stop production and leave the dairy market, or they seek to supplement their income by expanding their cheese production activity with part of their milk production.

(c) Market and institutional failures

There are four types of actors in the distribution of milk (Figure 3): the first is the dairy farmer conducting the direct sale of the daily production quota of fresh milk allocated and purchased by Liconsa; the second is the dairy farmers conducting direct distribution, of an integrated nature, for use in the production of cheese either in their small and medium-sized enterprises or in their family workshops. The third is an intermediary who collects milk from dairy farmers (any dairy producers or traders) and becomes a supplier of milk to cheese or confectionery companies The fourth is an intermediary working as an importing distributor who markets imported milk powder and vegetable fats and supplies the parastatal company Liconsa and local cheese companies. In the four cases, the actors are different for each market, but they assume the risks of marketing the fresh milk and, in the case of the importers, they cover the costs of transport, border entry, storage and logistics necessary for the imported milk powder as well as the marketing of the necessary inputs for rehydration (e.g., vegetable fats) [57].

Additionally, in the fresh milk market, the prices controlled in the territory by Liconsa do not contribute to maintaining the economic profitability of dairy farmers, which can lead to an improvement in their income through increased livestock production linked to a greater number of heads per hectare, causing overgrazing, which in the medium term leads to a degradation of the livestock land, as in the initial explanation. Under such conditions of vulnerability of dairy farmers, productive social differentiation generates diverse strategies related to cheese production. In the case of large farmers, the strategy tends to integrate their dairy production with the establishment of small and medium-sized industrial cheese enterprises; in contrast, for small farmers, the strategy is to establish family workshops for the sale of fresh ranchero cheese.

The analysis shows some hints that productive social differentiation and unequal environmental degradation lead to divergent behavior and interests among dairy farmers and prevent collective action. These circumstances lead to market and institutional failures that result in a poor level of collective action and a lack of local governance that hinder the development of IPG cheese (Figure 4).

The market and institutional failures of cheese in the territory are iindicated by the lack of complete information to the consumer and the absence or lack of strict compliance with official sanitary regulations and quality certification of fresh ranchero cheese in the territory. While some large dairy producers seek to improve their economic profitability by adulterating (using vegetable fat) or counterfeiting (Cotija cheese) the industrial cheese product, some small dairy producers market cheeses in poor sanitary conditions. These market failures mean that the fresh ranchero cheese market is seen as a second or marginal market with low prices.

\section{Discussion}

The above analysis shows that there is a local cheese production system in the Cienega de Chapala, Michoacan, that has a tradition of almost five hundred years, which today operates a group of dairy farmers who assume their social identity as ranchers and independent producers but are disorganized and are experiencing a growing process of social differentiation and environmental degradation. This affects the local production system and causes it to lose opportunities to develop a PGI good based on its traditional fresh ranchero cheese that is in popular demand in a short regional food circuit.

In the territory, there are no forms of governance of the value chain or of territorial management, and in the market, prices are defined by a parastatal that acquires a part of the local dairy supply and, together with small and medium-sized cheese companies, buys imported milk powder and vegetable fats, which lowers milk prices in the territory. The recent signing of the USMCA in 2020 guarantees the continued importation of milk, 
and the only solution is a territorial public policy that distinguishes raw cow milk from imitation dairy products from both parastatal and fake cheese production.

However, specialty goods are always attractive to oligopolistic interests. This is why, at the moment, changes in food quality federal laws affect them, because they can no longer produce imitation cheeses as easily as before. Generally, medium-sized local cheese companies can quickly be bought out by large corporations to produce fake cheeses. Therefore, the only solution to defend the specialty good of small dairy farmers is through collective action to enforce the new laws, defend their regional marginal market through a system of local governance and develop PGI cheese.

The sole application of existing laws and regulations is not enough. Collective action by the social actors involved is required. This requires the recognition of each social actor, the development of their own form of organization and the discussion of points of convergence and divergence of interest between large and small dairy farmers, as well as between representatives of family cheese workshops and local cheese companies. The creation of a professional services platform with the participation of local research centers would make it possible to take advantage of existing research and extension infrastructures in the territory and would contribute to the development of a territorial governance system for milk and fresh cheese.

The results of the MFA and ATLAS.ti analyses, although they cannot fully explain these issues, show at least at a partial level that there are two issues within the nature of the obstacles faced by dairy farmers in the territory: (a) socio-environmental problems and (b) institutional and market failures of the local cheese in their territory. Both are not recognized as such but have a decisive influence on productive social inequality and on the specific behavior of large and small dairy farmers, as well as on their relationship with the market.

The hindrances to generating a good PGI stemming from these two problems are as follows: on the one hand, the lack of the collective action of dairy farmers, given that they are divided by their different strategies in the face of socio-environmental problems, and on the other hand, the preference for the functioning of a marginal market with low prices for their cheese, given the absence of local governance to resolve the market failures of fresh ranchero cheese in the territory (e.g., its territorial quality, use of $100 \%$ cow's milk and food safety are not certified or guaranteed). In spite of everything, the paradox is that fresh ranchero cheese from the Cienega of Chapala, Michoacan, has a local social distinction and a regional popular marketing circuit (Jalisco and Michoacan), and there is even a social demand abroad, based on the family chains of migrants.

Skilton and $\mathrm{Wu}$ [58], writing on territorial governance, argue that the heterogeneity of the capacities of the producer and the different interests of the social actors involved act inversely proportionally to the level of coordination of the producers and their commitment to PGI goods. There are ways to reduce heterogeneity and generate a process of confluence to common interests, but this depends on the organizational quality of the social actors involved, the ability to establish mechanisms of territorial control and governance and a greater commitment from the producers of PGI goods. In this regard, for the case study of the Cienega of Chapala, these authors indicate the importance of organized social discipline that can incorporate dairy farmers, large and small, that serves to recognize a common good based on good environmental, agro-productive, sanitary and commercial practices and that can even allow the existence of different economic profitability strategies according to scale size (e.g., serving different markets, expansion of differentiated goods).

Mancini and Arfini [59] delve into short food supply chains (SFSCs) by stating that they are part of market flexibility strategies for producers of specialty goods because the operation of these short chains allows them to generate social, environmental and relational benefits that strengthen the social identity of the producer and strengthen the institutional system of the PDO and PGI goods. They indicate that currently, the neo-artisanal chain of PDO Parmesan cheese competes with a grana Padano cheese that is also a mature cheese but is industrially processed and of a lower price than Parmesan, which is marketed in cities 
and with reduced fat and calories. The strategy of direct approach to the final consumer is implemented by marketing in its own place of sale, reducing costs, improving its social reputation and strengthening consumer confidence. These lessons deserve to be reflected in the case of the Cienega of Chapala due to the presence of heterogeneity of dairy and cheese producers in a context of market failures but with a still-functioning regional food circuit and an increasing demand from migrants in the United States for this product.

Arfini et al. [60] associate the existence of PGI goods with the provision of public goods, pointing out that three types of public goods are provided by the development of PGI goods: the conservation of landscape heritage, socioeconomic benefits and good management of natural resources. These types of goods are distributed throughout the territory to develop sustainable practices, strengthen the capacity of social resilience and allow significant social learning processes in terms of linking sustainable development to a rising quality of life. In other cases, such as that of the meat of the Sierra de Guadarrama (Spain), despite having a regional short food circuit, the PGI good has shown market and governance failures that prevented it from more effectively promoting sustainable territorial development [61].

Belletti et al. [62] state that any of the problems in GI construction are mainly based on the activation of GI valorization initiatives due to failures in collective action, lack of empowerment and self-esteem on the part of local stakeholders, scarce knowledge about their territorial asset and lack of capacity to reconcile the divergent interests of the parties and resolve market failures (p. 53).

In their study on the relationship between PGIs and the provision of public goods, they provide three key aspects: The first is that the definition of public good (as a non-excludable and non-rival) is limited, and currently a public good is defined by conventions, collective action and public policy. In the case of the social construction of a PGI, the public utility of a PGI good lies not only in the consumption aspect but also in production; for PGIs, not only the tangible (produced with local resources) but also the intangible (local collective decision-making on PGIs) should be considered.

The second is that five profiles of publicness can be found in PGI goods: (a) the specific features in the productive process that define the quality of the good; (b) the economic, social and territorial effects (employment, income and social cohesion); (c) the role of PGI goods as territorial public goods; $(\mathrm{d})$ the role of the geographic indication as a collective right over the geographical name due to the productive chain of the PGI; and (e) the PGI good as a cultural or symbolic public good and its protection due to its existence value and its character as a heritage good.

The third is that the publicness of the PGI good lies in the well-functioning of its successful economic model, which is based on the generation of added value throughout the production process of the PGI good due to the recognition of consumers and the constant support of the collective actions of the actors in the value chain. This requires maintaining the economic viability of the companies in the PGI good value chain, preserving the knowledge and trust of consumers in the links between the quality of the good and its origin and preserving the specific local resources that determine the specific quality of the PGI good's territory and function as a sustainable economic system.

For the purpose of this work, returning to the work of Mancini and Arfini is relevant given that a PDO good, being a specialty good, acts as a common good aimed at satisfying the needs of a regional social consumer through its short food circuits. We also need to resolve how the role of this specialty good is established as part of the strategy of developing a territorial basket of goods that works by linking with these short food circuits. Again, these considerations are useful not only for the case of the Cienega de Chapala but also for understanding that food systems must be sustainable [63] and be based on an approach of economic circularity. 


\section{Conclusions}

To conclude, we return to the question of why there are hindrances to the development of fresh ranchero cheese from the Cienega of Chapala, Michoacan, as a PGI good.

According to the low explanatory power of the results of the MFA analyses, we can say that at least partial relationships were found pointing out that the obstacles faced by dairy farmers in the territory are due to the existence of two problems: socio-environmental problems and local cheese market and institutional failures.

It is possible that with a better selection of variables and a modification in the treatment of some aspects such as the environment, social organization and social identity, the model might work better. However, there remains the question raised by one reviewer as to whether such models are truly effective or limited in nature due to the rich complexity of the problem being addressed.

Regarding analysis with ATLAS.ti, it is necessary to mention that it was useful in helping us to understand the functioning of dairy farmers' value chain relationships and markets. In turn, this allowed us to understand the framework of relationships between collective action and the obstacles to the development of the PGI cheese.

The obstacles to considering fresh ranchero cheese as a PGI good generated by these two problems are (a) the inability to constitute a collective action of dairy farmers, due to their different interests and strategies in the face of socio-environmental problems, and (b) the absence of a local governance system that addresses the market failures of fresh ranchero cheese in the territory, such as the lack of certification or guarantee of its territorial quality, its production from $100 \%$ cow's milk, its food safety and the use of good sustainable practices in the value chain and good environmental practices for conservation of the landscape heritage of the territory. Furthermore, the lack of a local governance system does not contribute to the implementation of the current national policy of quality protection and correct food labeling of the federal government in the territory of Cienega de Chapala, Michoacan.

In this sense, it is necessary to build effective, democratic and decentralized forms of territorial governance with the collective action of the social actors involved, the support of an interprofessional body and interaction with local scientific and academic institutions that, in collaboration with the official authorities, can preserve the landscape heritage of PDO and PGI goods.

The concerns raised by dairy farmers' associations and families owning cheese dairies to resolve the market and institutional failures they face can be a starting point for the development of collective action in a context of changes in federal laws on product quality. Here, it is key to highlight the importance of the publicness nature of the PGI and to consider its development in the territory as a sustainable development strategy for the provision of a public good with landscape heritage. With the information collected, the dialogue with farmers will continue through livestock associations, seeking as the next objective the formation of cooperatives and agreements to achieve goals such as a GI for cheese produced in the area.

Here, it is perhaps important to remember that Acemoglu et al. [64] proposed, from the neoinstitutionalist approach, as in long-term development, the existence of inclusive political institutions, that is, institutions that guarantee pluralism in society, which allow power games [65] between political, social and economic actors and their struggle for hegemony to exist, as long as what prevail in the end are the contractual relationships established by all participants, who are included and accepted as beneficiaries of this development. In this sense, its extrapolation in the discussion about the hindrances to the PGI status that ranchers in the Cienega de Chapala face may be important in the social construction of organizational and institutional capacities in that territory.

The work was done with the associations of local farmers over low prices of milk and the groups of family cheese workshops participating in research on food safety. These social actors seek to solve the problem of market and institutional failures and the urgency 
of adapting to the new quality standards of cheese products. We see this as a way of starting to develop their capacity for collective action.

Author Contributions: M.d.R.P.-L.: objective, introduction, issue, conceptual framework, and analysis of results, discussion of results. P.P.R.-C.: objective, issue, methodology, and analysis of results. G.C.-C.: objective, methodology and analysis of results. R.F.-M.: issue and analysis of results. All authors have read and agreed to the published version of the manuscript.

Funding: This research received no external funding.

Institutional Review Board Statement: Not applicable.

Informed Consent Statement: Not applicable.

Data Availability Statement: https://drive.google.com/drive/folders/11TXBjNiSV17w5HUSFYEQ74711Ge8MjX?usp=sharing accessed on 9 February 2020.

Acknowledgments: We thank the Consejo Nacional de Ciencia y Tecnología-CONACYT and the Instituto Politécnico Nacional for their support in carrying out this research. We acknowledge the Project SIP 20201099. We also thank the local livestock associations of the municipalities of Jiquilpan, Marcos Castellanos, Sahuayo and Venustiano Carranza of the state of Michoacán for their collaboration. We are deeply grateful to all reviewers for their valuable comments that improved this work.

Conflicts of Interest: The authors declare no conflict of interest.

\section{References}

1. FAO. COVID-19 and the Role of Local Food Production in Building More Resilient Local Food Systems; FAO: Rome, Italy, 2020. Available online: https:// doi.org/10.4060/cb1020en/ (accessed on 12 December 2020).

2. Arfini, F; Mancini, M.C. Local institutions and territorial competitiveness in the case of Parmigiano Reggiano localised production system. In Proceedings of the 2nd AIEAA Conference between Crisis and Development: Which Role for the Bio-Economy, Parma, Italy, 6-7 June 2013; Italian Association of Agricultural and Applied Economics (AIEAA): Parma, Italy, 2013.

3. Pérez-Akaki, P. Denominaciones de Origen e instituciones: Análisis de las experiencias mexicanas. In Saberes de Origen, Experiencias de México y Centroamérica; Pérez-Akaki, P., Gonzá-lez-Cabañas, A., Picado-Umaña, W.C., Eds.; UNAM-FES Acatlán: Mexico City, Mexico, 2018; pp. 41-68.

4. Pensado-Leglise, M. Los cambios en la división internacional del trabajo agrícola y sus efectos en la dinámica espacial de los sistemas agroalimentarios: El caso de México. In Proceedings of the 116th EAAE seminar "Spatial Dynamics in Agri-food Systems: Implica-tions for Sustainability and Consumer Welfare", Parma, Italy, 27-30 October 2010.

5. Allaire, G.; Sylvander, B. Qualité spécifi que et innovation territoriale. Cah. Écon. Sociol. Rural. 1997, 44, 29-59.

6. Ilbery, B.; Kneafsey, M. Niche Markets and Regional Speciality Food Products in Europe: Towards a Research Agenda. Environ. Plan. A Econ. Space 1999, 31, 2207-2222. [CrossRef]

7. Feenstra, G.W. Local food systems and sustainable communities. Am. J. Altern. Agric. 1997, 12, 28-36. [CrossRef]

8. Renting, H.; Marsden, T.K.; Banks, J. Understanding Alternative Food Networks: Exploring the Role of Short Food Supply Chains in Rural Development. Environ. Plan. A 2003, 35, 393-411. [CrossRef]

9. Rallet, A. L'économie de proximités. Etudes Rech. Syst. Agraires Dév. 2002, 33, 11-25.

10. Chiffoleau, Y. Circuits courts alimentaires, dynamiques relationnelles et lutte contre l'exclusion en agriculture. Économie Rural. 2012, 332, 88-101. [CrossRef]

11. Maréchal, G. Comercio justo y circuitos cortos de comercialización: El rol del estado en Brasil. In La comida de aquí. Retos y realidades de los circuitos cortos de comercialización; González-Cabañas, A., Nigh, R., Pouzenc, M., Eds.; CIMSUR: San Cristóbal de Las Casas, Mexico, 2019. Available online: https://halshs.archives-ouvertes.fr/halshs-01502453 (accessed on 28 April 2020).

12. Loconto, A.; Jimenez, A.; Vandecandelaere, E.; Tartanac, F. Agroecology, local food systems and their markets. Mono-graphic Section: Territorial Governance of Short Supply Chain in Local Food Systems Rationale. Rev. Ager. Rev. Estu-Dios Sobre Despoblación Desarro. Rural. 2018, 25, 13-42.

13. Sylvander, B.; Allaire, G.; Belletti, G.; Marescotti, A.; Barjolle, D.; Thevenod-Mottet, E.; Tregear, A. Qualité, origine et globa-lisation: Justifications générales et contextes nationaux, le cas des Indications Géographiques. Rev. Can. Sci. Rég. 2006, 29, 43-54.

14. Buchanan, J.M. An Economic Theory of Clubs; Economica, R., Ed.; Wiley: Hoboken, NJ, USA, 1965; Volume 32, pp. 1-14, New Series.

15. Ostrom, E. Governing the Commons. The Evolution of Institutions for Collective Action; Cambridge University Press: Cambridge, UK, 1990.

16. Kizos, T.; Vakoufaris, H. What is the extent of short food supply chains in Greece? Evidence from the cheese supply chains in the North Aegean Region. Int. J. Agric. Resour. Gov. Ecol. 2011, 9, 48. [CrossRef] 
17. Caswell, J.A. Uses of Food Labelling Regulations; OECD: Paris, France, 1997; Document: OCDE/DG (97) 150. Available online: http:/ / www.oecd.org/officialdocuments/publicdisplaydocumentpdf/?cote=OCDE/GD(97)150\&docLanguage=En (accessed on 6 April 2020).

18. Hirschman, E.C.; Holbrook, M.B. Hedonic Consumption: Emerging Concepts, Methods and Propositions. J. Mark. 1982, 46, 92. [CrossRef]

19. Sylvander, B. La qualité: Du consommateur final au producteur. Etudes Rech. Syst. Agraires Dév. 1994, 28, 27. Available online: https://hal.archives-ouvertes.fr/hal-01231571/document (accessed on 6 April 2020).

20. Belletti, G.; Casabianca, F.; Marescotti, A. Local food quality and local resources. In Local Agri-Food Systems in a Global World: Market, Social and Environmental Challenges; Arfini, M., Mancini, C., Donati, M., Eds.; Cambridge Scholars Publishing: Newcastle Upon Tyne, UK, 2012; p. 71. Available online: https://hal.archives-ouvertes.fr/hal-01354016/document (accessed on 6 April 2020).

21. Barjolle, D.; Sylvander, B. Protected Designations of Origin and Protected Geographical Indications in Europe: Regulation or Policy? Recommendations; European Commission, PDO and PGI Products: Market, Supply Chains and Institutions. European Comission. Project coordinator: France (INRA - UREQUA), Project partners: France (CRISALIDE) - Greece (NAGREF) - Italy (CRPA) - The Netherlands (WAU), Switzerland (EPFZ) - United Kingdorn (Wye College, University of London); European Union: Brussels, Belgium, 2000; FAIR 1-CT 95-Final Report.

22. Linck, T. Patrimonialisation et Typification de Fromages Traditionnels: Une Approche Comparée de Démarches de Qualifica-tion. Ruralia 2005, 16, 1-15. Available online: http:/ /journals.openedition.org/ruralia/1086 (accessed on 22 December 2020).

23. Bowen, S.; Zapata, A.V. Geographical indications, terroir, and socioeconomic and ecological sustainability: The case of tequila. $J$. Rural. Stud. 2009, 25, 108-119. [CrossRef]

24. Barjolle, D.; Chappuis, J.-M. Transaction Costs and Artisanal Food Products. Actas de la 2000, 1, 1-17. Available online: https://www.academia.edu/3082771/Transaction_costs_and_artisanal_food_products (accessed on 9 February 2020).

25. Vázquez, A.M. Acción colectiva y desarrollo rural: Las instituciones de organización de la calidad. Cooperativismo y Desarrollo 2016, 23. Available online: https:/ / revistas.ucc.edu.co/index.php/co/article/view/1248 (accessed on 6 April 2020). [CrossRef]

26. Tregear, A.; Arfini, F.; Belletti, G.; Marescotti, A. Regional foods and rural development: The role of product qualification. J. Rural. Stud. 2007, 23, 12-22. [CrossRef]

27. Pecqueur, B. Qualité et développement territorial: l'hypothèse du panier de biens et de services territorialisés. Économie Rural. 2001, 261, 37-49. [CrossRef]

28. Alban, T.; Lamine, C.; Allès, B.; Chiffoleau, Y.; Doré, A.; Dubuisson-Quellier, S.; Hannachi, M. The Key Roles of Economic and Social Organization, Producer and Consumer Behaviour Towards a Health-Agriculture-Food-Environment Nexus: Re-cent Advances and Future Prospects; Toulouse School of Economics, INRAE: Paris, France, 2020. Available online: https://www.tse-fr.eu/sites/default/ files/TSE/documents/doc/wp/2020/wp_tse_1068.pdf (accessed on 4 October 2020).

29. Reyes-Aceves, F.; Vela-Reyna, J.B.; Muñoz-del, R.G. Los Retos de una Paraestatal Productora de Leche en el Posiciona-Miento de Marca; UANL: Nuevo León, Mexico, 2020; pp. 565-570.

30. Filonov, A.; Tereshchenko, I.; Monzon, C.; Avalos-Cueva, D.; Pantoja-González, D. Climatic Change in a Large Shallow Tropical Lake Chapala, Mexico. In Lake Sciences and Climate Change; IntechOpen: London, UK, 2016; pp. 3-24.

31. Lara, P.D.L.; Sánchez, R.D.R.; Téllez, M.A.R. La Ciénaga de Chapala, Michoacán: Cambios y permanencias en la construcción regional. Relac. Estud. Hist. Soc. 2015, 36, 237-259. [CrossRef]

32. Moreno, M.E.N.D. El surgimiento de la ganadería en la Ciénega de Chapala (Michoacán, México). El caso de la Hacienda Guaracha (siglos XVI-XIX). Hist. Rev. Hist. Reg. Local 2014, 6, 185-219. [CrossRef]

33. Brading, D. Haciendas y Ranchos del Bajío: León 1700-1860; Grijalbo: Mexico City, Mexico, 1988.

34. Moreno-García, H. Haciendas de tierra y agua en la antigua Ciénega de Chapala; El Colegio de Michoacán: Zamora, Mexico, 1989.

35. Rivera-Espinoza, P.; Álvarez-Macias, A. Reestructuración de la producción primaria de leche en el sur de jalisco ante el pro-ceso de globalización. Rev. Mex. Agronegocios 2005, 9, 479. Available online: http://www.redalyc.org/articulo.oa?id=14101607 (accessed on 14 October 2020).

36. Torres, R.; Barragán-López, E. Hábitat de la cultura ranchera en la sierra de Jalisco y Michoacán, México. Potencial para el aprovechamiento de un turismo biocultural. Int. J. Sci. Manag. Tour. 2016, 2, 281. Available online: https://dialnet.unirioja.es/ descarga/articulo/5744224.pdf (accessed on 12 October 2020).

37. Villagrana, P.U.; Contreras, M.; Ángel, I. Sociedades rancheras del occidente mexicano: Balance historiográfico. Relac. Estud. Hist. Soc. 2018, 39, 37-69. [CrossRef]

38. Vera, J.H.C.; Escoto, F.C.; Rangel, M.I.P.; Vargas, A.C.; Ledesma, J.O. Especialización de los sistemas productivos lecheros en México: La difusión del modelo tecnológico Holstein. Rev. Mex. Cienc. Pecu. 2017, 8, 259. [CrossRef]

39. Semerena, R.E. El TLCAN en la agricultura de México: 23 años de malos tratos. Ola Financ. 2018, 11, 85-104. [CrossRef]

40. Villegas de Gante, A.; de la Huerta Benítez, R. Naturaleza, evolución, contrastes e implicaciones de las imitaciones de que-sos mexicanos genuinos. Estud. Soc. 2015, 23, 213-236.

41. González, M.; Rivadeneyra, F. La ley de un solo precio en México: Un análisis empírico. Gac. Econ. 2004, 10, 91. Available online: http:/ / biblat.unam.mx/es/revista/gaceta-de-economia/articulo/la-ley-de-un-solo-precio-en-mexico-un-analisis-empirico (accessed on 9 June 2020). 
42. Arellano, J.D.J.E.; Hernández, A.M.F.; Chavarría, S.L.; Gómez, F.M. Impacto de las importaciones de leche en polvo y derivados lácteos en el precio al productor de leche de bovino en México. Agric. Soc. Desarro. 2019, 1, 123-139. [CrossRef]

43. DOF. Norma Oficial Mexicana NOM-155-SCFI-2012. In Leche-Denominaciones, Especificaciones Fisicoquímicas, Información Comercial y Métodos de Prueba; Diario Oficial de la Federación: Mexico City, Mexico, 2012. Available online: http:/ /dof.gob.mx/ normasOficiales/4692/seeco/seeco.htm (accessed on 25 March 2020).

44. CODEX Alimentarius. Norma para Mezclas de Leche Desnatada (Descremada) y Grasa Vegetal en Polvo, Norma CXS251-2006, Adoptada en 2006. Enmendada en2010, 2013, 2014, 2016, 2018. Available online: http://www.fao.org/ fao-who-codexalimentarius / sh-proxy / en / ?lnk=1\&url=https $\% 253 \mathrm{~A} \% 252 \mathrm{~F} \% 252 \mathrm{Fw}$ orkspace.fao.org $\% 252 \mathrm{Fsites} \% 252 \mathrm{Fcodex} \%$ 252FStandards\%252FCXS\%2B251-2006\%252FCXS_251s.pdf (accessed on 16 July 2020).

45. DOF. Norma Oficial Mexicana NOM-190-SCFI-2012. In Mezcla de Leche con Grasa Vegetal-Denominaciones, Especificaciones Fisicoquímicas, Información Comercial y Métodos de Prueba; Diario Oficial de la Federación: Mexico City, Mexico, 2012. Available online: https: / / www.dof.gob.mx/nota_detalle.php?codigo=5266143\&fecha=31/08/2012 (accessed on 29 July 2020).

46. DOF. Norma Oficial Mexicana NOM-223-SCFI/SAGARPA-2018. In Queso-Denominación, Especificaciones, Información Comercial y Métodos de Prueba; Diario Oficial de la Federación: Mexico City, Mexico, 2019. Available online: https://dof.gob.mx/nota_detalle. php? codigo $=5549319 \&$ fecha $=31 / 01 / 2019$ (accessed on 8 September 2020).

47. DOF. Modificación a la Norma Oficial Mexicana NOM-051-SCFI/SSA1-2010. In Especificaciones Generales de Etiquetado para Alimentos y Bebidas no Alcohólicas Preenvasados-Información Comercial y Sanitaria; Diario Oficial de la Federación: Mexico City, Mexico, 2020. Available online: https:/ / www.dof.gob.mx/2020/SEECO/NOM_051.pdf (accessed on 23 March 2020).

48. Robledo Padilla, R. Política de producción y comercio de leche en México en el contexto actual. Abordajes Teór. Impactos Externos Políticas Públicas Din. Econ. Desarro. Reg. 2019, 1, 472. Available online: http://ru.iiec.unam.mx/4673/ (accessed on 3 May 2020).

49. DOF. Ley de Infraestructura de la Calidad. Cámara de Diputados del h. Congreso de la Unión. Secretaría General. Secretaría de Servicios Parlamentarios; Diario Oficial de la Federación: Mexico City, Mexico, 2020. Available online: http:/ /www.diputados.gob.mx/ LeyesBiblio/pdf/LICal_010720.pdf (accessed on 5 October 2020).

50. Bartholomew, D. Principal Components Analysis. In International Encyclopedia of Education; Elsevier: Amsterdam, The Netherlands, 2010; pp. 374-377.

51. Kassambara, A. Practical Guide to Principal Component Methods in R: PCA, M (CA), FAMD, MFA, HCPC, Factoextra; STHDA: Montpellier, France, 2017; Volume 2. Available online: http://www.sthda.com/english/articles/31-principal-componentmethods-in-r-practical-guide/ (accessed on 13 February 2020).

52. López-Roldán, P.; Fachelli, S. Análisis Factorial. Metodología de la Investigación Social Cuantitativa; Universidad Autónoma de Barcelona: Barcelona, Spain, 2016. Available online: https://ddd.uab.cat/pub/caplli/2016/163564/metinvsoccua_a2016_cap1-2 .pdf (accessed on 10 March 2020).

53. Quesada, F.J.M. Mapas conceptuales a partir de entrevistas cualitativas: Integración de métodos mediante el uso conjunto de ATLAS/ti y SPSS. Pap. Rev. Sociol. 2010, 95, 507. [CrossRef]

54. Varguillas, C. El uso de ATLAS. Ti y la Creatividad del Investigador en el Análisis Cualitativo de Contenido UPEL. Instituto Pedagógico Rural El Mácaro. Rev; Laurus: Caracas, Venezuela, 2006; Volume 12, pp. 73-87. Available online: https://www.redalyc.org/pdf/ 761/76109905.pdf (accessed on 14 May 2020).

55. Moncada-Herrera, J. El Análisis Factorial Múltiple: Un Paso más en la Superación de la Dicotomía Cualitativo-Cuantitatvo. VI Congreso Chileno de Antropología. Colegio de Antropólogos de Chile A. G, Valdivia. Available online: https://www. aacademica.org/vi.congreso.chileno.de.antropologia/ 67 (accessed on 23 October 2020).

56. Moraine, M.; Melac, P.; Ryschawy, J.; Duru, M.; Therond, O. A participatory method for the design and integrated assessment of crop-livestock systems in farmers' groups. Ecol. Indic. 2017, 72, 340-351. [CrossRef]

57. Gaudin, Y.; Padilla-Pérez, R. Los intermediarios en cadenas de valor agropecuarias Un análisis de la apropiación y genera-ción de valor agregado. Estud. Perspect. Sede Subreg. CEPAL México 2020, 186, 1-40.

58. Skilton, P.F.; Wu, Z. Governance Regimes for Protected Geographic Indicators: Impacts on Food Marketing Systems. J. Macromarketing 2013, 33, 144-159. [CrossRef]

59. Mancini, M.C.; Arfini, F. Short supply chains and Protected Designations of Origin: The case of Parmigiano Reggiano (Italy). Ager 2018, 25, 43-64.

60. Arfini, F.; Cozzi, E.; Mancini, M.C.; Ferrer-Perez, H.; Gil, J.M. Are Geographical Indication Products Fostering Public Goods? Some Evidence from Europe. Sustainability 2019, 11, 272. [CrossRef]

61. Pensado-Leglise, M.D.R.; Cañada, J.S. Valorización de una Indicación Geográfica Protegida. El caso de la carne de la Sierra de Guadarrama, España. Rev. Mex. de Cienc. Pecu. 2018, 9, 451-465. [CrossRef]

62. Belletti, G.; Marescotti, A.; Touzard, J.-M. Geographical Indications, Public Goods, and Sustainable Development: The Roles of Actors' Strategies and Public Policies. World Dev. 2017, 98, 45-57. [CrossRef]

63. Pensado-Leglise, M. Los Sistemas Agroalimentarios Sostenibles y los SIAL con Criterios Ambientales" Capítulo de Libro en Torres G. In Los Sistemas Agroalimentarios Sostenibles y el Consumo Local, ED; UNAM y Asociación Mexicana de Estudios Rurales: Mexico City, Mexico, 2014; pp. 69-91. 
64. Acemoglu, D.; Johnson, S.; Robinson, J. Institutions as the Fundamental Cause of Long-Run Growth. In Institutions as the Fundamental Cause of Long-Run Growth; National Bureau of Economic Research: Cambridge, MA, USA, 2004 ; pp. 386-472.

65. Pensado-Leglise, M. Los Juegos de Poder. Marco Institucional y Conflictos Socioambientales a Nivel Territorial en México en Pensado-Leglise M. y L. García-Serrano Coords. In Los Retos Actuales de las Ciencias Ambientales y de la Sustentabilidad en México. Ed; Altres Costa-Amic Editores: Puebla, Mexico, 2017; pp. 60-80. 